\title{
International Migration and Human Trafficking in Malaysia: A Study on Illegal Immigrants
}

\author{
Mohd Na'eim Ajis ${ }^{1}$, Kamarulzaman Askandar ${ }^{2} \&$ Saadon Awang ${ }^{1}$ \\ ${ }^{1}$ School of Government, College of Law, Government and International Studies, Universiti Utara Malaysia, \\ Malaysia \\ ${ }^{2}$ Faculty of Humanities, Art and Heritage, Universiti Malaysia Sabah, Malaysia \\ Correspondence: Mohd Na'eim Ajis, School of Government, College of Law, Government and International \\ Studies, Universiti Utara Malaysia, 06010, Sintok, Kedah, Malaysia. E-mail: naeim@uum.edu.my
}

Received: July 28, 2015 Accepted: October 13, 2015 Online Published: October 26, 2015

doi:10.5539/ass.v11n25p124 URL: http://dx.doi.org/10.5539/ass.v11n25p124

\begin{abstract}
Foreign immigrant mobilisation to a country is inheritable and in fact there are countries that encourage the entry of foreigners because they indirectly generate the country's income and increase the economic activities. Due to various factors that influence migration among migrants, some of them are willing to enter countries illegally and become illegal immigrants. Unfortunately, most foreign immigrants with the illegal immigrant status have been exploited by certain parties, merely to get profit. Therefore, this article will discuss and reveal the experience of some illegal immigrants who have been exploited, especially during their admission process and their involvement in the economic activities. This exploitation does not only happen to migrants with illegal immigrant status, those who enter a country using Temporary Work Permit Pass (TWPP) could also be victims. The study was conducted using three main approaches, namely surveys, interviews and group discussion. The study found that there were respondents who have been exploited by certain parties especially during admission process and employment. Some of the various types of exploitations are fraud, abuse, coercion, force and so on. In conclusion, immigrants are exposed to trafficking criminal activities and it does not only focus on illegal immigrants, but also on those who have entered legally.
\end{abstract}

Keyword: international migration, human trafficking, illegal immigrant, Malaysia

\section{Introduction}

Human trafficking is presumed as the oldest crime and has been detected since early history of mankind. Even then, this issue is looked at from a new angle in the past few years. Many government and international bodies around the world are discussing this issue and it is known as a crime that keeps increasing since the 1990s. Various factors have been associated with human trafficking issues. Such is globalisation, where it has encouraged the migration of people especially from poorer countries to richer countries. At the same time, there are other factors that can be associated with these crimes such as education level, job opportunity and other factors connected to migration (Miko, 2005). Konrad (2002) argued that the pull-push factors that occurred in both sending and receiving countries have played an important role in human trafficking activities. The pull factors occurred in home country of migrants like poverty, unemployment and political instability. Hence, the push factors consist of economic development and political stability in which occur in receiving countries. Human trafficking issues are now getting more serious and complex. It is also known as a universal industry and not answerable to any particular country. Those involved in the operation of these activities have gained multiple profits and the demand has also increased. According to the Trafficking in Persons Report by the United States Department of State, it is estimated that the parties involved in the human trafficking activities gain profits up to US\$1-3 billion every year. Victims involved in human trafficking are estimated at 600-800 thousand people all over the world. It is estimated that at least 14,500 to 17,800 people are trafficked into The United States each year (see United States Department of State, 2005). Meanwhile, International Labour Organization (ILO) report on Profits and Poverty: The Economics of Forced Labour stated that two thirds of the estimated total of US\$150 billion or US\$ 99 billion, came from commercial sexual exploitation, while another US\$51 billion resulted from forced economic exploitation, including domestic work, agriculture and other economic activities (ILO, 2014).

In Malaysia, human trafficking activities have become a new phenomenon in the transnational crime. Among 
those, most often associated with this crime is migrants and these migrants are increasing in volume in certain countries, therefore the challenge increases for the government to overcome transnational crimes. Their presence is most often described by certain parties as a national security threat. McGahan (2008) is of the opinion that in the 1997 economic crisis, migrants were not considered a security threat, but since the crisis, it is considered as a threat in terms of national security. This situation occurred because the elite society or the leaders managed to influence the citizens by making open statements regarding the implications of migrants to the country. They have associated migrants with various negative implications such as crimes and diseases. McGahan also reiterates that foreign immigrants especially those with illegal status are most probably easier to be human trafficking victims. This is because, they are easily exploited by certain parties especially agents or employees. The migration and human trafficking are elements that are very closely related. Even though in Malaysia there are many materials discussed on the migration related issues in journal, thesis, paper work etc but they are not relate migration with human trafficking specifically. Therefore, the article will discuss how the migrants have high risks of becoming the victims of human trafficking activities and the various ways they are exploited.

\section{What Is Human Trafficking?}

Before we discuss the issue of human trafficking, we need to understand the meaning of human trafficking in the legal context. This is because it will help us to describe and identify how an activity is classified as human trafficking crime and which element can convict a person as a human trafficking victim. Therefore, UN Convention on Transnational Organised Crime (2000) has defined human trafficking as:

"The recruitment, transportation, transfer, harbouring or receipt of person, by means of threat or other forms of coercion, of abduction, of fraud, of deception, of the abuse of power or of a position of vulnerability or of the giving or receiving of payments or benefits to achieve the consent of a person having control over another person, for the purpose of exploitation. Exploitation shall include, at a minimum, the exploitation of the prostitution of others or other forms of sexual exploitation, forced labour or services, slavery or practices similar to slavery, servitude or the removal of organs"

Section 2, Anti Trafficking in Person and Anti Smuggling of Migrants Act 2007 defined human trafficking as:

"all actions involved in acquiring or maintaining the labour or services of a person through coercion, and includes the act of recruiting, conveying, transferring, harbouring, providing or receiving a person for the purpose of this Act" (Note 1)

As for the definition of exploitation, section 2 defines it as:

"All form of sexual exploitation, forced labour or services, slavery or practices similar to slavery, servitude, any illegal activity or removal of human organs."

For the meaning of coercion, Section 2 defines it as:

a. Threat of serious harm or physical restriction towards anyone.

$b$. Any schemes, plan or pattern intended to cause a person to believe that failure to perform an act would result in serious harm to or physical restraint against any person; or

c. The abuse or threatened abuse of the legal process.

There are a few elements obtained from the definition of human trafficking, which are transfer or recruitment of persons, using deception or force and placing a person in exploitation. Gallagher (2001) on the other hand, believes that in order to decide the existence of human trafficking activities, it can be seen in various aspects, that is firstly the existence of recruitment, transfer, transportation, protection, harbouring and receipt of persons. Secondly, we need to identify the reasons for those actions whether it involves threat, force or any form of force, kidnapping, fraud, deception and abuse of power to give or receive payment or benefits to achieve consent from the person. Thirdly, the existence of exploitation at a minimum, exploitation of prostitution, other forms of sexual exploitation, forced labour or service, slavery or practices similar to slavery, servitude or organ transfer by force. Generally, human trafficking activities can be divided into two main categories that are employment and sexual aspect.

\subsection{Employment Trafficking and Forced Labor}

According to International Labour Organisation (2012) it is estimated that nearly 21 million men, women and children have become victims of forced labour globally, trapped in jobs into which they were coerced or deceived and which they cannot leave. Basically, trafficking in employment is part of trafficking in person's definition because basic human rights are violated here. What is most often neglected in the situation of trafficking in employment is the discussion to protect all the employees' basic rights without taking into account 
situation of the employee, exploitation and law status (Richard, 2004). In addition, victims of trafficking labour consists of cheap labour working in several sectors such as agriculture, construction, domestic service, food service, manufacturing and entertainment where they are hired illegally without any health and security insurance (Bakirci, 2009). Even then, the concept of labour trafficking in Malaysia can be associated with the existence of two elements, that is exploitation and involuntary. These two elements are considered essential in deciding whether an activity involves recruitment, transportation, transfer and receipt of the person as labour trafficking or not.

The United Nation's Trafficking In Person's Protocol (2000) has explained that labour trafficking involves involuntary element/force element or any form of force and therefore, in the context of trafficking in employment it can be associated when an employee's rights have been violated illegally, which involves unreasonable act of force and exploitation. Labour trafficking involves long term relationship between a trafficked person and a trafficker. This relationship prolongs until that employee is exploited whether by taking all the documents or work permit away, put a hold on payment, abuse and treating them badly as well as always threaten the employee that he will be reported to the authorities and be sent home. Therefore in 2003, Migrant Workers Convention was acknowledged as part of the international basic human rights law. Migrant Workers Convention makes sure the basic human rights, the way they are treated and migrant workers' welfare are protected regardless their status, legal or not. In addition to that, it states that legal foreign workers and their families are to be treated the same way as the local workers, in terms of law, politics, economically, socially and culturally (Richard, 2004).

Forced labour is a traditional issue that is always talked about. Labour situation could occur in terms of occupation or economic activity, including the employment process that is conducted. The important aspect in determining whether that person has become forced labour is the relationship that exists between the employee and employers, besides the danger and threats that exist in the working environment. This is because the concept of forced labour regardless of the nature of the job or status of the law or job, whether it is legal or not, but it is more focused to the pressure or force given by the employer towards his employee (ILO, 2005). If a person does a heavy or dangerous job voluntarily to support his family's expenses without involving pressure or force by any parties, it is not considered as a forced labour. This is because this action is done willingly and not forced, pressured or threatened by others. Forced Labour Convention 1930 has defined forced labour as:

All work or service which is exacted from any person under the menace of penalty and for which the said person has not offered himself voluntarily (Art. 2.1)

From the above definition, the word 'menace of penalty' is not focused upon the sentence aspect, but it is associated with the threat of losing rights or privileges of an employee. An employee is free to give consent to do a job or service. The word 'consent' is considered irrelevant if the consent was obtained by means of force, pressure, threat or fraud. Therefore, when a person is denied the right to get privilege on an employee, he is categorised as forced labour (see Stephen \& Linden, 2004).

\subsection{Sex Trafficking}

Sex trafficking is always associated with trafficking women and children in the sex industry or prostitution. This is considered as the most profitable trafficking activity and with the high technology communication systems in this era, this issue has become even more complex. Sex trafficking victims are often forced to engage in sexual activities such as prostitution, pornography, strip dance and adult massage parlours (Bakirci, 2009). The United States Department of State (2008) justified sex trafficking victims as those constantly facing threat if the trafficker's demands are not fulfilled. Victims of the sex trafficking will engage in paying sexual activities unwillingly and without their consent. In modern day slavery phenomenon, a human will be persuaded by the syndicate party to work as prostitute overseas and they will be given freedom to live. But on the other hand, these women are forced into sex slavery and used cruelly while the syndicate gains profit from these activities. Research by the Swedish government shows the highest profit is gained by the prostitution industry and these profits will be directly enjoyed by the human trafficking syndicate. According to International Labour Organisation (2005), women forced to work in prostitution are considered forced labour regardless the activity or job is legal. This is because involuntary element and the nature of the job where the victim is constantly under threats and this is the basis for exploitation elements which leads to human trafficking. Therefore, Bakirci (2009) says that women that become human trafficking victims are considered victims of crime and not forced labour. For children under 18 years of age, involuntary element does not have to be proven as part of defence in a human trafficking offence. 


\section{Research Methodology}

The focus of this research is the condition of illegal immigrants in Northern Region of Peninsular Malaysia, especially Penang, Kedah and Perlis. This research is using primary and secondary data which is collected using a few methods consist of survey, interview, observation, focused group discussion and library research. The interview has been done with authorities related to illegal immigrants' issues such as the Immigration Department, Smuggling Prevention Unit, Malaysian Army, Malaysian Maritime Enforcement Agency and Malaysia Trade Union Congress. At the same time, the researcher has also used focused group discussion with respondents in Illegal Immigrants Detention Centre in Belantik, Sik, Kedah to obtain the real picture using hands-on experience.

The research sample includes illegal immigrants detained in Belantik, Sik Kedah and also those who were once illegal immigrants or independent respondents. The sample has been taken randomly for control group respondent which is 54 detainees or 10 percent of the total detainees on that day, which were 543 detainees in total. For independent respondent, the researcher used focus group discussions and informal interviews. Most of the respondents were obtained in Alor Setar, Sungai Petani and Penang, especially among Myanmar refugees who entered Malaysia illegally before they were given the refugee status.

Besides interviews, the researcher also used observation method to obtain information regarding activities done by the illegal immigrants. The techniques used were such as visiting the border entry points, places where illegal immigrants are transited or smuggled, as well as a look into the community where illegal immigrants' activities occur, whether openly or in hiding. All data and information obtained were processed and analysed using descriptive analysis, where important matters were obtained via interviews and gathered and arranged according to thematic sequence with reference to objectives and research questions that were initially determined.

\section{Research Findings and Discusion}

In discussing human trafficking activities among illegal immigrants, researches have divided into a few discussion aspects that focus on various forms of exploitation that were experienced by the respondents whether during the entry process, documentation preparation and employment. The various forms of exploitation if related to the definition under ATIPSOM, it then becomes an offense of trafficking in persons.

\subsection{The Process of Entering Malaysia}

Table 1. Types of routes used

\begin{tabular}{llll}
\hline Type & Frequency & $\%$ & \% Cummulative \\
\hline Sea & 12 & 22.2 & 22.2 \\
Air & 28 & 51.9 & 74.1 \\
Land & 14 & 25.9 & 100.0 \\
Total & 54 & 100.0 & \\
\hline
\end{tabular}

About 51.9 percent respondents have used the air route compared to the rest, 25.9 percent used land and 22.2 percent used sea (see Table 1). Most of them travelled by air, used employment agent service and they come from geographically further countries such as Africa and Middle East regions. As for land and sea routes, immigrants are from neighboring countries or Southeast Asia such as Indonesia, India, Bangladesh, Thailand, Philippines, Myanmar, Vietnam and Cambodia. Even then, there are illegal immigrants from Asian countries that travel using airplanes to enter Malaysia due to the current cheap and affordable air transport. During the entry process most illegal immigrants used agent's service to be smuggled in using a certain payment rate. The rate of payment depends on the agreement between agent and migrant as well as transport facilities that were provided. Even then, there are illegal immigrants who fail to prepare the amount requested by agents to be smuggled in, so they were sold to certain parties. This situation was told by a Myanmar migrant who entered through Thailand:

\section{Case 1: Ahmed who became a victim of trafficking in persons and smuggling of migrants.}

Ahmed originates from Myanmar and had tried to enter Malaysia when he was 16 years old. Unfortunately, due to his failure to pay the complete payment to his agent, he was sold to be a fisherman for three years in Thailand (without salary and only given food to eat). After he was released, he was smuggled in by the agent through the Thailand-Kelantan border. While he was taking a walk in Kelantan, he was deceived by two Chinese locals who promised to get a job for him. He was then sold to a fisherman in Terengganu. He had to work as a fisherman for 
six month without salary. After that Ahmed was fortunate enough to meet a few fellow Myanmar citizens in Terengganu and they helped him run away to Penang.

The exploitation done by the agent to Ahmed shows that smuggling is a very profitable criminal activity as a migrant can be trafficked if he fails to fulfil the syndicate's demands. Ahmed can be considered a debt bonded labour, which means he had debts with the agent who brought him because he failed to pay the full amount of migration. Debt can be paid off in various ways by a migrant until a point where the person can be sold to other parties. In the situation, employer or agent has the power because they supported the migration cost. This shows that migrants, especially illegal ones, are easily exploited by certain parties to gain profit. According to Malaysia Trade Union Congress (MTUC), there are some cases in which some of foreign workers had to borrow money from agents to come to Malaysia. Based on the cases handled by MTUC, they found that there are foreign workers who were not paid for nearly a year on the basis that they must repay their loan to the agent. (Note 2) According to the Labour Department, employers can be prosecuted under the Employment Act 1955, if the do not pay the employee's wage for more than a month. Hence, if they do not pay for more than three months or cut more than 70 percent of employee's wage, they can be prosecuted under the ATIPSOM Act and this is regarded as a form of forced labour. (Note 3) The Immigration Department has verified that an agent or known as 'tekong darat' will impose between RM500 to RM2500 as the cost for smuggling a foreign worker. This also depends on the transportation facility given and security risk that the syndicate has to face at the border of Malaysia. (Note 4)

\subsection{Documentation}

Table 2. Types of documents used

\begin{tabular}{llll}
\hline Type & Frequency & $\%$ & \% Cummulative \\
\hline Passport & 39 & 72.2 & 72.2 \\
No documents & 14 & 25.9 & 92.1 \\
Forged passport & 1 & 1.9 & 100.0 \\
Total & 54 & 100.0 & \\
\hline
\end{tabular}

Table 2 shows that most illegal immigrants who enter do possess documentation; that is 72.2 percent have passports and work permits or only passports. Whereas those who do not have documentation are 25.9 percent and one of them used a fake passport. Most of them with documentation for their migration were based on employment factor or tourist using social visit pass. Even though these people have legal journey documentations to enter Malaysia, but they misused the documents by staying longer than they were allowed and also worked using social visit pass. At the same time, there are some other immigration offences such as running away from employer, working in a sector they did not apply for, forging documentation and furthering studies without student pass. Therefore those actions have made them part of the illegal category.

According to Azizah (2003) illegal workers or immigrants can be divided into three categories. First are those who enter the destination country and then stay in hiding because they do not have legal documents. They get jobs through informal channels based on relations, close friends and families who live in destination country. Second, are those who stay longer than the given time whether they are employees, tourists or students. Therefore, foreign workers who fail to renew working pass are also known as illegal immigrants. The third category consists of those who misuse employment contract. This situation occurs when a few employees who were legally hired leave the original employee and searches for a new job.

In the process of preparing immigration documentation, there are respondents who were cheated by the agent that brought them in. This situation was explained by an Indonesian respondent:

\section{Case 2: Kasno's Documentation was cheated by agents when he entered Malaysia}

"I originally come from Sulawesi and am 35 years old. I took a boat ride from Surabaya to Batam. In Surabaya, I was cheated by employment agents there. I gave them money worth RM550 and they promised to prepare documentations such as a passport and a work permit as well as to arrange my transportation to Malaysia. Unfortunately, those agents ran away with my money. I refused to turn back to Sulawesi and was determined to enter Malaysia regardless of the means because I was desperate to get a job. I thought that if I returned to my hometown, my life would be much harder because I can only work as a trishaw peddler, and I definitely wouldn't be able to upgrade my family's life. Eventually I was able to enter Malaysia with the help of my friends. In Batam, 
I already contacted a friend in Malaysia to wait in Johor. When I landed, my friend took me to Kuala Lumpur using his car. Upon arrival in Kuala Lumpur, we went to Penang to look for a job. While working in a construction site in Penang, I was captured by the authorities for not presenting a legal journey documentation."

This situation experienced by Kasno is a kind of trafficking in person crime. This is because according to the definition by UN Convention on Transnational Organised Crime (2000) and Anti Trafficking in Persons and Smuggling of Migrants Act (ATIPSOM), forgery and deception whether in the process of hiring or transportation is considered a kind of exploitation and it is a part of human trafficking crime. In fact, there are legal foreign workers management firms that have committed forgery. For example a case that happened in Shah Alam, Selangor a famous foreign worker's management firm for having many branches including in other states such as Johor and Penang, was alleged for deceiving nearly 500 foreigners around those area when they made a payment of nearly RM2 million. In fact these permit deals were not done in offices, but in restaurants and dark alleys (Karim, 2013).

\subsection{Managing Employment and Financing Trips}

Table 3 shows that most illegal immigrants came using the service of agents to manage their trips. This is because most illegal immigrants enter Malaysia using work pass and they were managed by agents. Agents who manage foreign workers are divided into two; registered and unregistered agents. Usually unregistered agents are the ones embezzling the money and spoiling the image of registered, out sourcing firms. According to respondents, the agents that they used to enter Malaysia were not only one, but could come up to five or six people depending on the situation.

Table 3. Parties managing the trip

\begin{tabular}{llll}
\hline Category & Frequency & $\%$ & \% Cumulative \\
\hline Family & 9 & 16.7 & 16.7 \\
Friend & 1 & 1.9 & 18.5 \\
Agent & 30 & 55.6 & 74.1 \\
Alone & 11 & 20.4 & 94.4 \\
Others & 3 & 5.6 & 100.0 \\
Total & 54 & 100.0 &
\end{tabular}

Most respondents who enter Malaysia legally especially those using work permits said that the agent who brought them in has deceived them. Various kinds of scams were done by the agent such as type of job, wage payment, work permit duration, work place and employer. There are some agents that promised to offer a job as factory operators but they ended up working as domestic maids, worse is when the worker is forced to do things that are against their Islamic beliefs, such as bathing dogs and eating pork. This situation was explained to the researcher by an Indonesian illegal immigrant:

\section{Case 3: Heni was deceived by agents}

32 year old Heni, a Muslim originating from Bandung, Indonesia, came to Malaysia on March 2009. She took a ferry from Bandung to Sumatera and passed Medan on her way to Penang. She used the service of an agent who was an acquaintance from her village, and paid RM1500 to the agent. She came to Malaysia with 15 others using social visit passports. In Penang, the agent took away all their passports and sent them to employers who needed them. She worked in Gelugor, Penang and was paid RM500 a month. The agent took all of her salary for the first 4 months. After working there for 7 months, she was sent to work as a maid in a Chinese employer's house. She worked there for 9 month before running away as she was forced to do things considered "Haram" from the Islamic point of view such as bathing dogs and eating pork nearly every day. After that, she was captured by the authorities when she stayed at a friend's house in Relau, Penang.

The case that happened to Heni is a type of forced labour definition discussed in the Forced Labour Convention 1930. In discussing the definition, Stephen and Linden (2004) believe the 'consent' in agreeing to do a job is considered irrelevant if the consent was achieved by force, threat, pressure and fraud. A person who is denied rights or if an employee's privilege is taken away, it can also be categorised as forced labour and is considered as employment exploitation. This situation happened to Heni when she was forced to bath dogs and consume pork while working with non-Muslim employers. Heni's case also proved that migrant or illegal immigrants have a potential to be human trafficking victims, especially when she is an illegal immigrant. In this situation when one 
is an illegal immigrant, employer or agent will always pose threat to them by saying he will be captured by the authorities. Therefore those parties can exploit illegal immigrants in many forms such as not paying them salary, long working hours, abuse and not providing proper shelter. According to Richards (2004) most immigrants either men or women, migrate to gain better economic life and job prospect. Due to their desperate situations, there is a high probability of entering illegally and becoming victims of human trafficking because they were exploited by their employers and agents.

Besides agents, there are others who helped the entry of respondents into Malaysia. They consists of families, friends, relatives and they are those who come on their own. Families or next of kin help them in various aspects including transportation and documentation. There are families and relatives who had to contact agents or illegal parties to help smuggle illegal immigrants into Malaysia. According to Azizah (1997) who studied on illegal immigrants from Indonesia, illegal entry could occur two ways, either via unregistered/unlicensed agents, or using migrant workers network among them. For the first mean, some of the employers will contact unregistered agents who have contact from sending countries, especially Indonesia. This is because most illegal foreign workers detected in Malaysia are from that country. After receiving certain information from the Malaysian agents, the Indonesian agents will look for potential workers with the criteria demanded by the employers. Therefore, the agents in the country will go searching for those potential candidates even all the way into the rural villages and persuade the candidates to migrate to Malaysia. On the other hand, the second mean is via informal network among immigrants who stay in Malaysia either legally or illegally. Some of the employers have taken advantage to get more workers especially from Indonesia via this network. Normally, employers will ask their workers to bring in friends or relatives from Indonesia to work in Malaysia. Through this channel, employers only pay a little commission to those workers who bring in their friends or relatives. With the presence of many illegal immigrants especially from Indonesia who live in squatters in big cities, many employers hire workers from those places. Research findings show that employers not only get domestic maids but also workers for other sectors as well. The squatters are not only temporary placement for illegal immigrants but also a place for refugees to hide, especially those who still have not gotten any jobs.

Table 4. Financing trips

\begin{tabular}{llll}
\hline Category & Frequency & $\%$ & \% Cummulative \\
\hline Family & 16 & 29.6 & 29.6 \\
Friend & 1 & 1.9 & 31.5 \\
Agent & 14 & 25.9 & 57.4 \\
Alone & 20 & 37.0 & 94.4 \\
Others & 3 & 5.6 & 100.0 \\
Total & 54 & 100.0 & \\
\hline
\end{tabular}

Table 4 shows how the respondents' journey to Malaysia was financed. Most of them supported themselves and a large part of the rest was financed by agents of families. There are respondents who financed themselves and had to sell land and livestock to travel to Malaysia but in the end were conned by the agents. This story was told by a Bangladeshi respondent:

"I met with an agent in Bangladesh and he suggested that I worked in Malaysia. He said the cost to work there will be around RM13,000 and I would earn up to RM1500 once I start working there. Therefore, I sold my land in my village to bear cost. Once I reached Malaysia, I was only given work permit for a year and didn't earn as much as promised. When I wanted to renew it the following year, the agent ran away and took off with my passport." (Note 5)

At the same time, there are respondents who get their finances from agents to get to Malaysia. Usually agents only bear the cost of transportation and passport and the rest had to be paid by the migrant himself. In fact, the cost charged by agents is different and depends on the various factors such as the distance between worker and the agent office and the relationship between the worker and the agent, if they have known each other the cost will be cheaper. According to Aswatini (2002) who studied on Indonesian female workers who worked overseas, one way used by Indonesian workers who want to work overseas other than workers hiring companies or more commonly known as Association of Indonesian Labour Export Companies (AILEC) is through a middle person or agent or in their local community called sponsor. According to respondents in this research, cost incurred for the journey by sponsor differs from one individual to another. It depends on various factors such as distance from 
home to employment registration office, and the relationship between sponsor and the worker, the cost is cheaper compared to those who have not previously met or known. However, there are some workers who were found borrowing money from sponsors and repaying them once they get jobs in destination country. With that reason, there are some who had to receive pay cuts for years.

Every immigrant who is financed by his agent must pay back to the agent via pay deduction from employer. However there are irresponsible agents who cut their salaries for up to two years although initially the agent promised a pay cut for only the first three to six months, depending on how much they earned and borrowed from agents. The experience was told by the respondent from Indonesia:

\section{Case 4: Tanty's had salary deduction for up to two years}

Originating from East Jawa, the 34 year old Indonesian has been in Malaysia since 2008 when she was in Indonesia, she worked as a farmer and earned an uncertain salary. She entered through land route that is the Kalimantan- Sarawak border using passport and work permit. Transportation and passport costs were supported by the agent. When she was in Indonesia, the agent promised to get her a job that paid RM1200 a month, but she was sent to work as a maid in Menglembu, Ipoh and received RM450 per month and the agent deducted her salary and only received RM180 a month for 1 year 4 months. Her passport was taken and kept by the agent. While she was working as a maid, she was abused by the employer and was often beaten using broom and rattan, slapped and kicked. When she could no longer bear the suffering she ran away and worked in a food premise in Ipoh. However while she was working there, she was captured by the authorities for not presenting legal travel documents and a work permit.

Tanty's experience shows how she was exploited in various ways such as employment deception, salary deduction up to two years and abuse by employers. Even though respondent entered with legal document which is Temporary Work Visit Pass (TWVP) but she was still exposed to exploitation element and is considered as part of human trafficking forms.

4.4 Type of Job and Working Hours

Table 5. Types of job and working hour

\begin{tabular}{llllllllllllll}
\hline \multirow{2}{*}{ Type } & \multicolumn{1}{c}{ Working hours per day } & \multicolumn{1}{c}{ Total } \\
& 5 & 6 & 7 & 8 & 9 & 10 & 11 & 12 & 16 & 20 & 24 & Not applicable & \\
\hline Production operator & 0 & 0 & 0 & 4 & 0 & 2 & 0 & 2 & 1 & 0 & 0 & 0 & 9 \\
Construction worker & 0 & 0 & 1 & 7 & 0 & 0 & 0 & 0 & 0 & 0 & 0 & 0 & 8 \\
Cook in a restaurant & 0 & 0 & 0 & 0 & 0 & 0 & 1 & 2 & 0 & 0 & 0 & 0 & 3 \\
Cashier & 0 & 0 & 1 & 1 & 0 & 0 & 0 & 0 & 0 & 0 & 0 & 0 & 2 \\
Maid & 0 & 0 & 0 & 0 & 1 & 2 & 0 & 1 & 0 & 3 & 0 & 0 & 7 \\
Fisherman & 0 & 0 & 0 & 0 & 0 & 0 & 0 & 0 & 0 & 0 & 1 & 0 & 1 \\
Business & 0 & 1 & 0 & 1 & 0 & 0 & 0 & 0 & 0 & 0 & 0 & 1 & 3 \\
Waiter & 0 & 0 & 1 & 2 & 1 & 0 & 0 & 0 & 0 & 0 & 0 & 0 & 4 \\
Rubber Tapper & 0 & 0 & 0 & 1 & 0 & 0 & 0 & 1 & 0 & 0 & 0 & 0 & 2 \\
Shop assistant & 0 & 0 & 0 & 1 & 0 & 1 & 0 & 1 & 0 & 0 & 0 & 0 & 3 \\
Technician & 0 & 0 & 0 & 1 & 0 & 0 & 0 & 1 & 0 & 0 & 0 & 0 & 2 \\
Collect oil palm & 0 & 0 & 1 & 0 & 0 & 0 & 0 & 0 & 0 & 0 & 0 & 0 & 1 \\
Cleaner & 1 & 0 & 0 & 0 & 0 & 0 & 0 & 2 & 0 & 0 & 0 & 0 & 3 \\
Not applicable & 0 & 0 & 0 & 0 & 0 & 0 & 0 & 0 & 0 & 0 & 0 & 6 & 6 \\
Total & 1 & 1 & 4 & 18 & 2 & 5 & 1 & 10 & 1 & 3 & 1 & 7 & 54 \\
\hline
\end{tabular}

Working hours are different depending on the nature of the job. Generally illegal immigrants work from 5 to 24 hours a day, and between 3 to 7 days a week. From the information obtained, it shows that the majority illegal immigrants work between 8-12 hours a day and between 6-7 days a week. Even then there are small numbers of them who says they work more than 20 hours a day. According to Malaysia Trade Union Congress (MTUC) there were cases handled by our officers where some workers had been exploited by agents and employers. For example the foreign workers who work as security guard, where the basic salary is RM 400 and they have been doing 'compulsory overtime' every day and just been paid RM350 in lump sum and not on hour basis. (Note 6) According to section 60A Employment act 1955, where the workers shall not be required to work more than 
eight hours in one day or more than forty-eight hours in one week. However, for those who work in shift basis the working hours are not more than twelve hours in a shift. For the overtime payment, the law prescribed that the workers must be paid 1.5 per hour (Note 7) or more than normal working hours paid. (Note 8 )

Table 6. Types of job and working days

\begin{tabular}{lllllll}
\hline \multirow{2}{*}{ Type } & \multicolumn{9}{c}{ Working days per week } & Total \\
& 3 & 5 & 6 & 7 & Not applicable & 9 \\
\hline Production operator & 0 & 0 & 7 & 2 & 0 & 8 \\
Construction worker & 0 & 0 & 6 & 2 & 0 & 3 \\
Cook in a restaurant & 0 & 0 & 1 & 2 & 0 & 2 \\
Cashier & 0 & 0 & 1 & 1 & 0 & 7 \\
Maid & 0 & 1 & 0 & 6 & 0 & 1 \\
Fisherman & 0 & 0 & 0 & 1 & 0 & 3 \\
Business & 0 & 0 & 1 & 1 & 1 & 4 \\
Waiter & 0 & 0 & 1 & 3 & 0 & 3 \\
Rubber Tapper & 0 & 0 & 1 & 1 & 0 & 2 \\
Shop assistant & 1 & 0 & 1 & 1 & 0 & 3 \\
Technician & 0 & 0 & 2 & 0 & 0 & 6 \\
Collect oil palm & 0 & 0 & 0 & 1 & 0 & 54 \\
Cleaner & 0 & 2 & 0 & 1 & 0 & 3 \\
Not applicable & 0 & 0 & 0 & 0 & 6 & 2 \\
Total & 1 & 3 & 21 & 22 & 7 & \\
\hline
\end{tabular}

Research findings also show that foreigners who stay here are willing to work hard anywhere, regardless of the nature of the job, and go through countless hours of work per week. This experience was shared by a respondent with the researcher:

"I only came to Malaysia to look for a job because in Indonesia, I could only work in a tobacco farm and my salary was equivalent to only RM6 per day. Therefore, when I came to Malaysia, I was determined to find a job regardless of what type of job it is and the nature of the job as long as I could handle it and get a good salary. Here, I worked as a construction worker with an Indonesian contractor and got paid RM60.00 per day. I am always protected by my employer here, he provides shelter and even food sometimes". (Note 9)

The respondent experience shows that the main objective hold by many foreign workers is survival which means they merely focus on how to get a job in destination country without concern about their service contract or working environment. The situation can impose difficulty in enforcement aspect because many exploited victims will do the job on voluntary manner and shall not log the report to authorities. Table 5 and Table 6 show more than 40 percent of the respondents work more than 10 hours a day and 80 percent of the respondents have worked between 6 to 7 days a week. This shows that the economic attraction has become a main factor for illegal immigrants to continue staying here. They are willing to work overtime up to 10 hours extra plainly because they want to earn as much they can. As for the employers, they have no objections to allow them to work for such long hours because they feel that there is no liability regarding employment and insurance protection on illegal immigrants from the law perspective. There are a few of them who admit that they were forced to work for more than 12 hours a day because they want to fulfil their customers' needs in the construction sector and restaurants. This shows that employers have used force and it is categorized as an element of human trafficking crime.

\section{Conclusion}

From the above research findings, it shows that some of the respondents have become victims of human trafficking when they are exploited by certain parties. The word 'exploitation' is clear enough in definition under the UN Convention on Transnational Organised Crime and ATIPSOM, which includes various types of exploitation such as recruitment, transfer, transportation as well as force elements like abuse and violence. At the same time, parties involved are mostly illegal agents who mostly only think about the profit they can gain from the crime conducted. As reported by the State Department of United States in 2005, profit gained from human trafficking activities are between USD 1-3 billion and the total number of victims involved is about 600 thousand to 800 thousand all over the world. As for UNODC report in 2009, it states that human trafficking is a criminal 
industry that has evolved rapidly, where it is estimate to have gained profit of up to $\$ 5$ and $\$ 9$ billion per year.

At the same time, parts of the human trafficking victims are workers with Temporary Work Visit Permit. But then due to irresponsible greedy agents who brought them, they were deceived. The most common deception is the type of position or job promised, permit duration, migration cost, total salary and many more. In fact, there are agents who bring them in and hold or purposely throw away the respondent's passport in order to make them illegal workers. When they become an illegal worker, it will make it easier for the agent or employers to threaten them and indirectly they will be easily exploited. The type of threat most often used by agents or employers is that they will be caught by authorities because they do not have legal travel documents and therefore be sent back home. If the worker has been caught before by the authorities for the same offence, then they can be caned for up to 6 times. Therefore illegal immigrant status owned by the migrant will allow them to be easily exploited by certain parties, either physically, mentally or psychologically.

Hence, it is obvious that exploitation among migrants is associated with human trafficking and has occurred in various similar situations, either in employment, documentation or entry process. Trafficking activity is not only limited to illegal immigrants, but those who enter legally and possess legal documents have also been exploited by criminals. Although this crime has increased and especially among migrants, the total number of foreigners entering Malaysia keeps increasing whether it is for the purpose of employment, tourism or education. The increasing number of foreigners especially for the purpose of employment and seeking political asylum has caused a concern that the number of human trafficking victims will also increase. A part of them have no choice because the country of origin lacks development and Malaysia's economic development has become a pulling factor for them to migrate to Malaysia, even though they know the risks they have to face. This is because rationally a person will decide to migrate due to salary difference and job opportunities in another country even though they do not know how true it is. This situation shows that the migrants will migrate to improve their life status as they have reacted towards the imbalanced economic difference between their country of origin and the destination country.

\section{References}

Bakirci, K. (2009). Human Trafficking and Force Labour: A Criticism of the International Labour Organization. Journal of Financial Crime, 16(2), 160-165. http://dx.doi.org/10.1108/13590790910951830

Gallagher, A. (2001). Human Rights and The New UN Protocols n Trafficking and Migrant Smuggling: A Preliminary Analysis. Human Rights Quarterly, 23(4), 975-1004. http://dx.doi.org/10.1353/hrq.2001.0049

International Labour Office. (2005). A Global Alliance Against Forced Labour. Geneva: ILO.

International Labour Office. (2012). Global Estimate of Forced Labour 2012. Geneva: ILO.

International Labour Office. (2014). Profits and Poverty: The Economics of Forced Labour. Geneva: ILO.

Karim, H. (2013). Permit palsu kaut RM2 juta (Forge permit gained RM2 million) (p. 46). Harian Metro.

Kassim, A. (1997). Illegal alien labour in Malaysia: Its influx, utilization and ramifications. Indonesia and the Malay World, 71, 50-82. http://dx.doi.org/10.1080/13639819708729889

Kassim, A. (2003). International Migration: Prospects And Challenges In Malaysia. In M. Y. H. Johari, \& C. S. Yaw (Eds), Reinventing Sabah: Global Challenges And Policy Responses. Kota Kinabalu: Institute For Development Studies.

Konrad. H. (2002). Trafficking in Human Beings-the Ugly Face of Europe. Helsinki Monitor, 13(3), 260-271. http://dx.doi.org/10.1163/157181402401452924

Legal Research Board. (2005). Employment Act 1955 (Akta 265) \& Regulations and Order. Kuala Lumpur: International Law Book Services.

Legal Research Board. (2012a). Anti-Human Trafficking in Person and Anti-Smuggling of Migrant 2007 (Act 670). International Law Book Services: Kuala Lumpur.

Legal Research Board. (2012b). Immigration Act 1959/63 (Act 155) and Regulations \& Pasport Act 1966 (Akta 150). International Law Book Services: Kuala Lumpur.

McGahan, K. (2008). Managing Migration: The Politics of Immigration Enforcement and Border Control in Malaysia. Phd Thesis. University of Wisconsin-Madison.

Miko, F. (2005). Trafficking in Women and Children: The U.S and International Response. CRS Report for Congress.

Raharto, A. (2002). Indonesian Female Labour Migrants: Experiences Working Overseas (A Case Study Among Returned Migrants in West Java). Paper Presented at the 2002 IUSSP Regional Population Conference on 
Southeast Asia's Population in a Changing Asian Context. Bangkok, Thailand, 10-13 June 2002.

Richrads, K. (2004). The Trafficking of Migrant Workers: What are the Links Between Labour Trafficking and Corruption? International Migration, 42(5), 147-168. http://dx.doi.org/10.1111/j.0020-7985.2004.00305.x

Stephens, S., \& Linden, M. V. D. (2005). Trafficking of Migrant Workers from Albania: Issues of Labour and Sexual Exploitation. Working Paper In Focus Programme on Promoting the Declaration on Fundamental Principles and Rights at Work. Geneva: International Labour Office.

United Nations. (2000). United Nation Convention againts Transnational Organized Crime: Annex II Protocol to Prevent, Suppress and Punish Trafficking in Persons, Especially Women and Children. Treaties and International Agreeents Registered with Secretariat of the United Nations.

US State Department. (2005). Trafficking in Person Report. Washington DC: Department of State.

US State Department. (2008). Trafficking in Person Report. Washington DC: Department of State.

\section{Notes}

Note 1. The main focus of this Act is exploitation. The human trafficking is occurred if there is exploitation imposed.

Note 2. Interview with President of MTUC, at Wisma MTUC, Subang Jaya, on 18 November 2013.

Note 3. Paper presented by En. Mohamed Yusof Abdul Hamid, Labour Department (Perlis Branch), Ministry of Human Resource on "Issues and problems in an effort exterminating forced labour under ATIPSOM in Modern Day Slavery Seminar: Trafficking in Person Crime and Smuggling of Human on 14 Disember 2013 at UniMAP Kapitol Hall, Kangar, Perlis, organized by Institute of Malaysia and International Studies and Universiti Malaysia Perlis (UniMAP).

Note 4. Interview with Immigration Department of Malaysia (Kedah Branch) at Bukit Kayu Hitam Immigration Department office on 21 May 2010.

Note 5. Focus group discussion with respondents from Bangladesh at Immigration Detention Centre Belantik, Sik, Kedah on August 8, 2010.

Note 6. Interview with President of MTUC at Wisma MTUC, Subang Jaya, Selangor, on 18 November 2013.

Note 7. The payment also depends on the public holiday which stated in Act whether it is gazette or not gazette public holiday.

Note 8. Legal Research Board, 2005, Employment Act 1955 (Act 265) \& Regulations and Order, International Law Book Services, Kuala Lumpur.

Note 9. Focus group discussion with respondents from Indonesia at Immigration Detention Centre, Belantik, Sik, Kedah on August 8, 2010.

\section{Appendix}

Mohamed Yusof Abdul Hamid. 2013. "Issues and problems in an effort exterminating forced labour under ATIPSOM" in Modern Day Slavery Seminar: Trafficking in Person Crime and Smuggling of Human on 14 December 2013 at UniMAP Kapitol Hall, Kangar, Perlis, organized by Institute of Malaysia and International Studies (IKMAS) and Universiti Malaysia Perlis (UniMAP).

Interview with Kedah Immigration Department at Bukit Kayu Hitam Immigration Office on May 21, 2010.

Interview with President of Malaysia Trade Union Congress (MTUC) at Wisma MTUC di Subang Jaya, on November 18, 2013.

\section{Copyrights}

Copyright for this article is retained by the author(s), with first publication rights granted to the journal.

This is an open-access article distributed under the terms and conditions of the Creative Commons Attribution license (http://creativecommons.org/licenses/by/3.0/). 